\title{
Areologia i natryskiwanie cieplne w ujęciu systemowym z uwzględnieniem zjawiska synergizmu
}

\author{
Areology and thermal spraying as functional \\ and physical systems with consideration \\ of synergism phenomena
}

\section{Streszczenie}

Podano informacje dotyczące systemu areologicznego natryskiwania cieplnego, omówiono jego istotę i odmiany, przedstawiono modele funkcjonalne i fizyczne. Omówiono różnice między właściwościami elementów systemu, a właściwościami sumy elementów systemu areologicznego. Zaproponowano wprowadzenie pojęcia współczynnika synergizmu do oceny jakości systemu i do kwantyfikowania właściwości systemu. Podano kilka przykładów współczynnika synergizmu technologii.

\section{Abstract}

The principles of areology system of thermal spraying on done, the essence of areological system of thermal spraying was described and the functional and physic models of areological system was presented. The difference between properties of elements system and properties of the sum of system elements was discussed. On propose to introduce the synergism of coefficient to valuation of quality of areological system and to qualification of properties system. On done some examples of synergism of coefficient of technology.

\section{Wstęp}

Inżynieria powierzchni zwana obecnie areologią jest jedyną $z$ technik wytwarzania powstałą $w$ zasadzie od momentu pojawienia się człowieka. Wraz z rozwojem ludzkości pojawiały się kolejne techniki wytwarzania warstw powierzchniowych o właściwościach odpowiadających potrzebom człowieka. Znanych jest kilka grup technologii wytwarzania warstw powierzchniowych, jedną $z$ nich jest natryskiwanie cieplne [1].

Mimo, że inżynieria powierzchni znana jest od wielu lat - nazwa ta pojawiła się dopiero w latach 70 . ub.w., podczas gdy pojęcie metalizacji natryskowej - bo tak pierwotnie nazywano natryskiwanie cieplne (natryskiwano tylko metale i stopy) - znane było już

Prof. dr hab. inż. Tadeusz Burakowski - Politechnika Koszalińska. pół wieku wcześniej [1]. Początkowo pojęcie inżynierii powierzchni obejmowało w zasadzie tylko techniczne aspekty kształtowania warstw powierzchniowych, pojawiło się pojęcie areologii - jako dyscypliny technicznej obejmującej również naukowe aspekty kształtowania. Utrwaliła się również nazwa natryskiwania

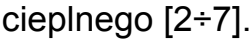

Nazwy areotechnika lub inżynieria powierzchni obejmują wszystkie techniki wytwarzania warstw powierzchniowych, a jedną $z$ nich jest natryskiwania cieplne powłok - technika powstała ok. 100 lat temu, rozwijając się dynamicznie, bez niej rozwój techniki nie osiągnąłby dzisiejszego poziomu.

W tablicy I podano najważniejsze etapy milowe rozwoju natryskiwania cieplnego, na rysunkach $1 \div 5$ podział, zastosowanie i rozwój areologicznych systemów powłokowych natryskiwania cieplnego, a w tablicy II podstawowe dane urządzeń do natryskiwania cieplnego. Na rysunku 2 - orientacyjne obszary parametrów: temperatura - prędkość cząstek materiału powłokowego, możliwych do uzyskania różnymi technikami natryskiwania cieplnego. 
Tablica I. Rozwój chronologiczny najważniejszych osiągnięć związanych z natryskiwaniem cieplnym (na podstawie [1])

Table I. The most important achievements of thermal spraying (acc to [1])

\begin{tabular}{|c|l|c|}
\hline Lata & \multicolumn{1}{|c|}{ Osiągnięcia } & Miejsce \\
\hline 1909 & M.U. Schoop opracowuje pistolet natryskowy tyglowy & Szwajcaria \\
\hline $1912 \div 1913$ & M.U. Schoop i in. opracowują pistolet natryskowy płomieniowy, proszkowy (1912) i drutowy (1913) & Szwajcaria \\
\hline 1914 & M.U. Schoop opracowuje pistolet natryskowy łukowy & Szwajcaria \\
\hline $1939 \div 1940$ & S. Reinecke opracowuje pistolet natryskowy plazmowy & Niemcy \\
\hline $1955 \div 1956$ & R.M. Poorman i in. nanoszą detonacyjnie cząstki na podłoże metalowe & Stany Zjednoczone \\
\hline 1960 & R. Stetson i C. A. Hauck natryskiwują plazmowo w atmosferze regulowanej & Stany Zjednoczone \\
\hline 1973 & E. Mühlberger stosuje natryskiwanie plazmowe w próżni & Niemcy \\
\hline 1982 & J. Browning stosuje natryskiwanie naddźwiękowe & Stany Zjednoczone \\
\hline 1985 & N. Papyrin opracowuje pistolet do natryskiwania cieplnego powłok na zimno & ZSRR \\
\hline
\end{tabular}

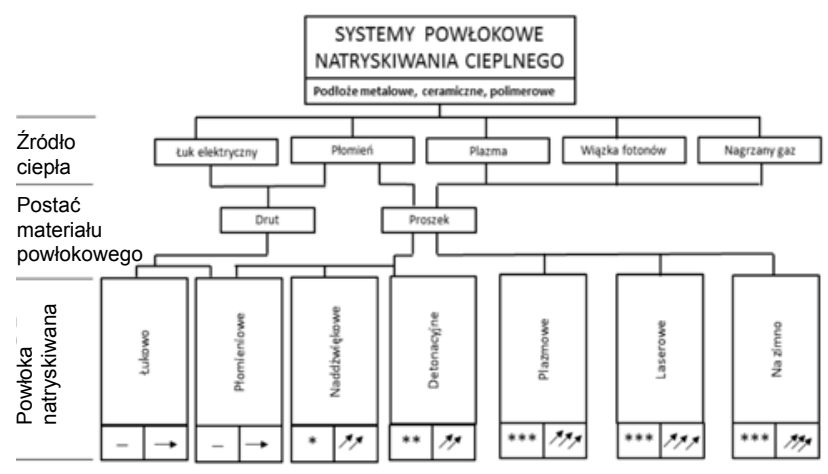

Rozwój: - brak, "słaby, "* sredni, "** szybki

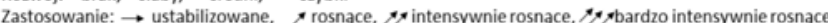

Rys. 1. Podział, zastosowanie i rozwój areologicznych systemów powłokowych natryskiwania cieplnego

Fig. 1. Classification, applications and development of thermal spraying areological systems

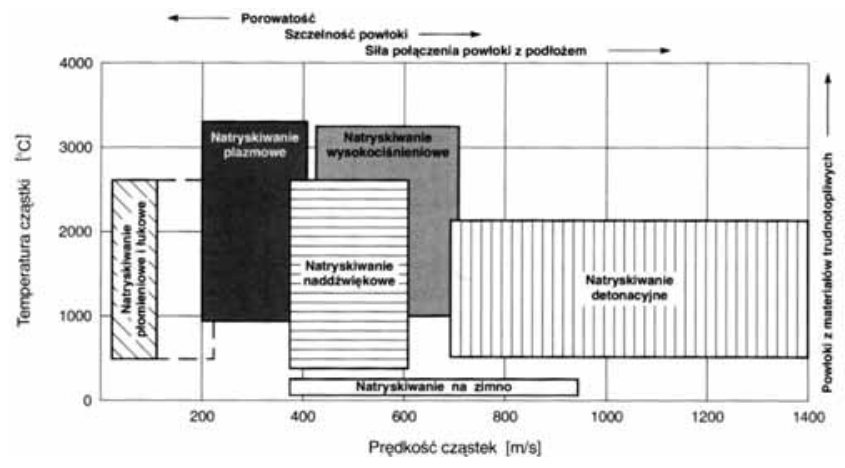

Rys. 2. Orientacyjne zakresy prędkości - temperatura cząstek, właściwe dla różnych metod natryskiwania cieplnego i kierunki zmian właściwości (głównie wg [3] i na podstawie skorygowanych danych $z$ [4])

Fig. 2. Approximate values of particle velocity as a function of temperature for different thermal spraying methods and trends of the properties of coatings, based on $[3,4]$

Tablica II. Charakterystyka sposobów natryskiwania cieplnego [3]

Table. II. Characteristic of thermal spraying methods [3]

\begin{tabular}{|c|c|c|c|c|c|c|c|c|c|c|}
\hline \multirow{2}{*}{\multicolumn{2}{|c|}{$\begin{array}{l}\text { Rodzaj urządzenia } \\
\text { natryskowego (pierwsze } \\
\text { zastosowanie) }\end{array}$}} & \multirow{3}{*}{$\begin{array}{c}\text { Gaz } \\
\text { acetylen, etan, } \\
\text { tlen, wodór, } \\
\text { propan }\end{array}$} & \multicolumn{2}{|c|}{ Źródła ciepła } & \multicolumn{2}{|c|}{ Materiał powłokowy } & \multicolumn{2}{|c|}{$\begin{array}{c}\text { Natryskiwane } \\
\text { cząstki }\end{array}$} & \multicolumn{2}{|c|}{$\begin{array}{c}\text { Wydajność } \\
\mathrm{kg} / \mathrm{h}\end{array}$} \\
\hline & & & rodzaj & $\begin{array}{l}\text { temperatura } \\
{ }^{\circ} \mathrm{C}\end{array}$ & rodzaj & postać & $\begin{array}{c}\text { prędkość } \\
\mathrm{m} / \mathrm{s}\end{array}$ & $\begin{array}{c}\text { rozmiar } \\
\mathrm{mm}\end{array}$ & metal & ceramika \\
\hline \multirow{2}{*}{$\begin{array}{c}\text { Pistolet } \\
\text { płomieniowy }\end{array}$} & $\begin{array}{l}\text { proszkowy } \\
(1912)\end{array}$ & & płomień & $<3160$ & wszystkie & proszek & $<50$ & $5 \div 100$ & $3 \div 6$ & $1 \div 2$ \\
\hline & $\begin{array}{c}\text { drutowy } \\
\text { (1913) }\end{array}$ & $\begin{array}{l}\text { acetylen, etan, } \\
\text { tlen, wodór, } \\
\text { propan }\end{array}$ & płomień & $<3160$ & $\begin{array}{l}\text { głównie } \\
\text { metale }\end{array}$ & drut & $<200$ & $5 \div 100$ & \multicolumn{2}{|c|}{$6 \div 8$} \\
\hline \multicolumn{2}{|c|}{$\begin{array}{l}\text { Pistolet łukowy } \\
\text { (1914) }\end{array}$} & - & $\begin{array}{c}\text { łuk } \\
\text { elektryczny }\end{array}$ & $\sim 4000$ & $\begin{array}{c}\text { wyłącznie } \\
\text { przewodzący } \\
\text { prąd }\end{array}$ & drut & $\sim 159$ & - & \multicolumn{2}{|c|}{$8 \div 20$} \\
\hline \multicolumn{2}{|c|}{$\begin{array}{l}\text { Pistolet plazmowy } \\
(1939-1940)\end{array}$} & $\begin{array}{l}\text { acetylen, etan, } \\
\text { tlen, wodór, } \\
\text { propan }\end{array}$ & plazma & do 20000 & wszystkie & proszek & $<400$ & $5 \div 100$ & \multicolumn{2}{|c|}{$4 \div 8$} \\
\hline \multicolumn{2}{|c|}{$\begin{array}{c}\text { Działo detonacyjne } \\
\text { (1955) }\end{array}$} & acetylen, etan & płomień & $>3200$ & wszystkie & proszek & $<1000$ & $5 \div 60$ & \multicolumn{2}{|c|}{$3 \div 6$} \\
\hline \multicolumn{2}{|c|}{$\begin{array}{c}\text { Wiązka laserowa } \\
\text { (1964) }\end{array}$} & $\begin{array}{c}\mathrm{CO}_{2} \text {, tlen, hel, } \\
\text { neodym, argon } \\
\text { i mieszaniny }\end{array}$ & $\begin{array}{l}\text { wiązka } \\
\text { fotonów }\end{array}$ & $>10000$ & wszystkie & proszek & $>1$ & - & \multicolumn{2}{|c|}{$1 \div 2$} \\
\hline \multicolumn{2}{|c|}{$\begin{array}{l}\text { Pistolet naddźwiękowy } \\
\text { (1982) }\end{array}$} & $\begin{array}{l}\text { acetylen, etan, } \\
\text { tlen, wodór, } \\
\text { propan }\end{array}$ & płomień & $<3160$ & wszystkie & proszek & $<600$ & $5 \div 45$ & $4 \div 8$ & $2 \div 4$ \\
\hline \multicolumn{2}{|c|}{$\begin{array}{l}\text { Pistolet do natryskiwania } \\
\text { na zimno (1985) }\end{array}$} & - & $\begin{array}{l}\text { nagrzany } \\
\text { gaz }\end{array}$ & $600 \div 750$ & $\begin{array}{c}\text { prawie } \\
\text { wszystkie }\end{array}$ & proszek & - & - & - & - \\
\hline
\end{tabular}




\section{Modele funkcjonalne systemów areologicznych i natryskiwania cieplnego}

System areologiczny (S.A.) jest uporządkowanym wewnętrznie układem w postaci zbioru areologicznego elementów materialnych powiązanych strukturalnie ze sobą, działających wspólnie i oddziałujących na siebie, aby osiągnąć określony cel (lub cele) działania niemożliwy do osiągnięcia przez poszczególne elementy [3]. Elementami SA są: rdzeń R, warstwa wierzchnia WW i powłoka P; mogą one być traktowane jako podsystemy, np. mogą uwzględniać kolejne modyfikacje WW lub rodzaj i liczbę powłok $P$ (rys. 3). Wielkościami wejściowymi są właściwości elementów oraz czynniki powodujące transformacje właściwości.

W zależności od podwójnej ( $R+W W$ ) lub potrójnej $(R+W W+P)$ kompozycji elementów systemów - rozróżnia się systemy areologiczne: rdzeniowy SAR i powłokowy SAP (rys. 4).

Zależnie od sposobu wytwarzania (i materiału) powłoki rozróżnia się główne grupy areologicznych systemów powłokowych:

- malarskie (powłoki niemetalowe),

- galwaniczne (powłoki metalowe),

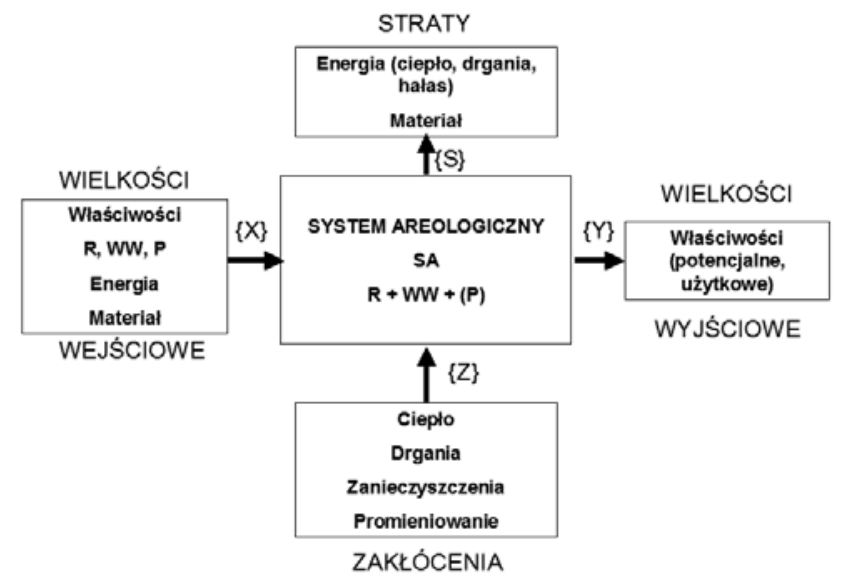

Rys. 3. Model funkcjonalny systemu areologicznego

Fig. 3. Functional model of areological system

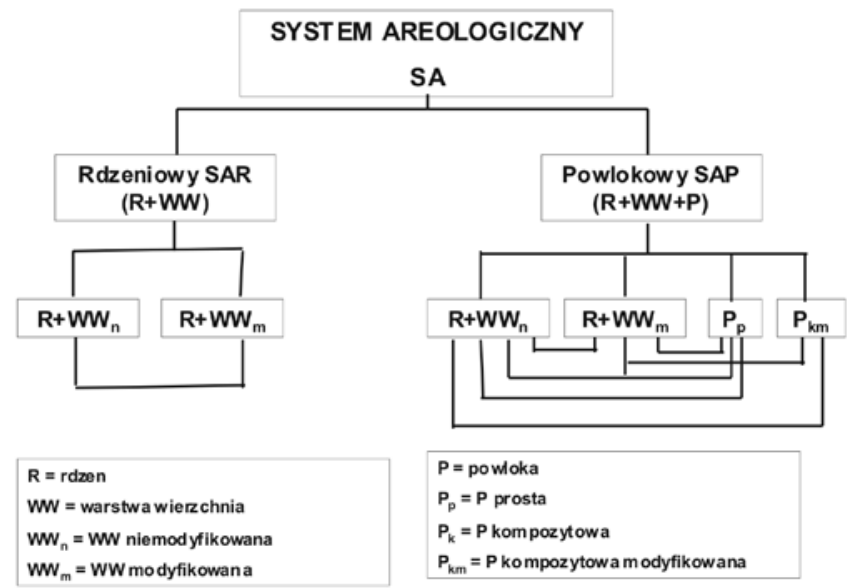

Rys. 4. Ogólny schemat systemu areologicznego [7]

Fig. 4. Scheme of areological system [7]
- PVD i CVD (powłoki metalowe i niemetalowe),

- zanurzeniowe (powłoki metalowe i niemetalowe),

- natryskiwane cieplnie (powłoki metalowe i niemetalowe).

W systemach areologicznych natryskiwania cieplnego SANC można z kolei wyróżnić podsystemy zależne od sposobu uzyskiwania i nagrzewania cząstek materiału powłokowego (tabl. II):

- płomieniowe (w tym naddźwiękowe),

- łukowe,

- plazmowe,

- detonacyjne,

- laserowe,

- uzyskiwane na zimno.

Funkcją SANC, podobnie jak każdego systemu, jest transformacja wielkości wejściowych (właściwości) w wyjściowe (właściwości inne lub o innych wartościach), tak aby uzyskać żądane właściwości potencjalne i/lub użytkowe systemu, przy czym główną rolę w tym systemie odgrywa powłoka.

Funkcją SANC jest nadanie obrabianemu elementowi żądanych właściwości podczas wytwarzania i utrzymanie w czasie użytkowania właściwości zabezpieczających element przed szkodliwym wpływem otoczenia. W związku z tym można wyróżnić systemy SANC: wytwarzany i użytkowany (eksploatowany). Podczas użytkowania następuje transformacja właściwości użytkowych.

\section{Modele fizyczne systemów areologicznych i natryskiwania cieplnego}

W modelu fizycznym rozpatruje się rzeczywiste relacje wzajemne elementów fizycznych systemów areologicznych i natryskiwania cieplnego.

Model fizyczny systemu areologicznego SA stanowi warstwową kompozycję różnych materiałów lub tych samych chemicznie materiałów, lecz o różnych właściwościach fizycznych, uzyskiwany w ramach procesu technologicznego wytwarzania i służy do uzyskania żądanych właściwości powierzchniowych kompozycji materiałów, przy czym właściwości sytemu zmieniają się w trakcie eksploatacji. W ogólności kompozycja warstwowa może być podwójna $(R+W W)$ lub potrójna $(R+W W+P)$, w szczególności WW może być wielokrotnie modyfikowana (rys. 5). Rdzeń i jego warstwa wierzchnia WW tworzą podłoże dla powłoki. Naniesiona na podłoże powłoka P może być wielowarstwowa: modyfikowana $\mathrm{P}_{\mathrm{m}}$ lub kompozytowa $P_{k}$ (rys. 6) [3].

Model fizyczny systemu natryskiwania cieplnego SANC stanowi fizyczną kompozycję warstwową materiałów: podpowłoki, powłoki natryskiwanej cieplnie i ewentualnie dla systemów dupleks - jednej lub kilku powłok malarskich. 


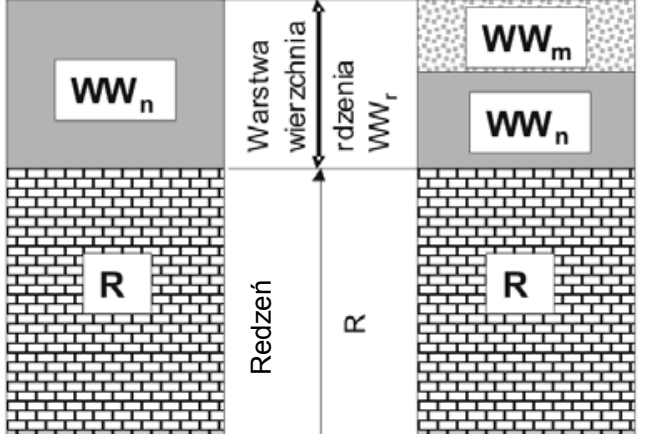

Rys. 5. Uproszczony model fizyczny systemu areologicznego rdzeniowego SAR z warstwą wierzchnią [7]: a) niemodyfikowaną (WW ${ }_{n}$ ); b) modyfikowaną (WW

Fig. 5. Simplified physical model of the areological core system $(\mathrm{SAR})$ with surface layer [7]: a) unmodified $\left.\left(\mathrm{WW}_{\mathrm{n}}\right), \mathrm{b}\right)$ modified $\left(\mathrm{WW}_{\mathrm{m}}\right)$

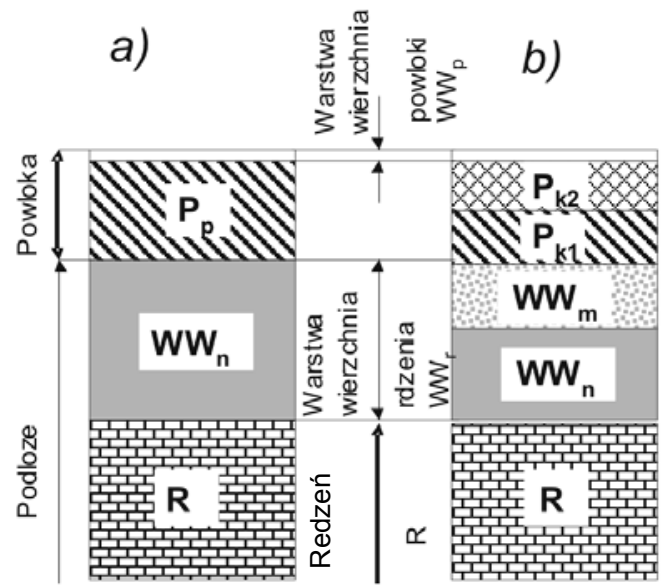

Rys. 6. Uproszczony model fizyczny systemu areologicznego powłokowego SAP [7]: a) warstwa wierzchnia niemodyfikowana $\left(\mathrm{WW}_{\mathrm{n}}\right)$ i jednowarstwowa (prosta) powłoka $P_{p}$; b) warstwa wierzchnia niemodyfikowana $\left(\mathrm{WW}_{\mathrm{n}}\right)$, modyfikowana $\left(\mathrm{WW}_{\mathrm{m}}\right)$ i powłoka kompozytowa $\left(P_{k}\right)$ dwuwarstwowa $\left(P_{k 1}, P_{k 2}\right)$

Fig. 6. Simplified physical model of areological superficial system (SAP) [7]: a) unmodified surface layer $\left(\mathrm{WW}_{\mathrm{n}}\right)$ and one-layer coating $\left(P_{p}\right)$; b) unmodified surface layer $\left(W W_{n}\right)$, modified surface layer $\left(\mathrm{WW}_{\mathrm{m}}\right)$ and double-layer composite coating $\left(\mathrm{P}_{\mathrm{k} 1}, \mathrm{P}_{\mathrm{k} 2}\right)$

Powłoka natryskiwana cieplnie może być również modyfikowana, np. uszczelniana laserowo (przez nadtopienie) lub ewentualnie implantowana jonami różnych pierwiastków. Niemodyfikowana powłoka natryskiwana cieplnie, stykając się z otoczeniem uzyskuje własną warstwę wierzchnią $\mathrm{WW}_{\mathrm{p}}[3,7]$.

\section{Właściwości elementów systemu i systemu elementów}

Podobnie jak w areologii, tak i w technice natryskiwania cieplnego nie powinno się rozpatrywać oddzielnie właściwości elementów systemu i ich sumę traktować jako właściwości systemu, lecz zawsze należy rozpatrywać właściwości całego systemu, ponieważ:

- system nie po to został stworzony z elementów, aby je rozpatrywać oddzielnie,

- elementy systemu nie zawsze mogą występować oddzielnie, np. system rdzeniowy $(\mathrm{R}+\mathrm{WW})$ może występować samodzielnie, ale nigdy nie występuje sama WW bez rdzenia i powłoka $P$ bez podłoża.

W skali makroskopowej rdzeń R, warstwa wierzchnia WW i powłoka $P$ stanowią odrębne fazy, a między fazami występuje mniej lub bardziej wyraźnie zarysowana granica międzyfazowa, przez którą fazy oddziałują na swoje właściwości [7].

Niekiedy autorzy, badając właściwości syste$\mathrm{mu}$ areologicznego lub natryskiwania cieplnego ( w postaci $R+W W$ lub podłoże $(R+W W)+$ powłoka $\mathrm{P})$, np. twardość, mierząc ją od strony powierzchni podają, że jest to twardość WW lub P. W ogólnym przypadku jest to błędna (lub przynajmniej nieścisła) informacja, gdyż mierzona twardość jest łączną odpowiedzią systemu $R+W W$ lub $(R+W W)+P$ na wciskanie wgłębnika $[3,7]$. Podobnie: inna będzie odporność korozyjna systemu: podłoże $\mathrm{Sn}+$ powłoka P1 i podłoże $Z n+$ powłoka $\mathrm{P} 1$, podobnie jak twardość systemu Pb + TiN lub SW7M + TiN, mimo że w obydwóch przypadkach powłoki P1 i TiN są takie same. Oczywiście w niektórych przypadkach właściwości mierzone systemu mogą być tożsame z właściwościami jednego z elementów systemu, np. twardość powłoki $z$ twardością systemu $z$ tą powłoką, ale tę tożsamość należy traktować jako szczególny przypadek ogólnej zasady.

\section{Synergizm kompozycji materiałów i technologii systemów areologicznych i natryskiwania cieplnego}

Właściwości potencjalne i użytkowe systemów areologicznych i natryskiwania cieplnego zależą od składu chemicznego, fazowego, morfologii elementów sytemu i ich kompozycji. Wpływ rodzaju i właściwości elementów systemu na właściwości systemów (o ile występuje) może być synergiczny lub antagonistyczny.

Systemy areologiczne i natryskiwania cieplnego wytwarza się po to, aby uzyskać określone właściwości systemu. Najczęściej wykorzystuje się synergiczne, znacznie rzadziej - antagonistyczne oddziaływanie elementów systemu. Najlepiej by było, aby elementy systemu nie stanowiły - pod względem materiałowym i technologii wytwarzania - dowolnej kombinacji, lecz ich synergiczną kompozycję. Odpowiedź na pytanie, czy dla określonych kombinacji materiałowo-technologicznych występuje synergizm, a jeśli tak, to jaka jest 
jego wartość, daje współczynnik oddziaływania [3]:

$$
k_{\circ}=\frac{a}{a_{1}}
$$

elementów układu $a_{1}, \ldots, a_{n}$ na dowolną właściwość układu. Jest to krotność zmiany określonej właściwości w wyniku działania dwóch lub więcej czynników, odniesiona do właściwości wywołanej działaniem jednego czynnika $a_{1}$. Gdy oddziaływanie na siebie czynników jest konstruktywne, czyli zwiększające łączny efekt - wówczas występuje synergizm oddziaływania i współczynnik oddziaływania $\mathrm{k}_{\mathrm{o}}$ przyjmuje nazwę

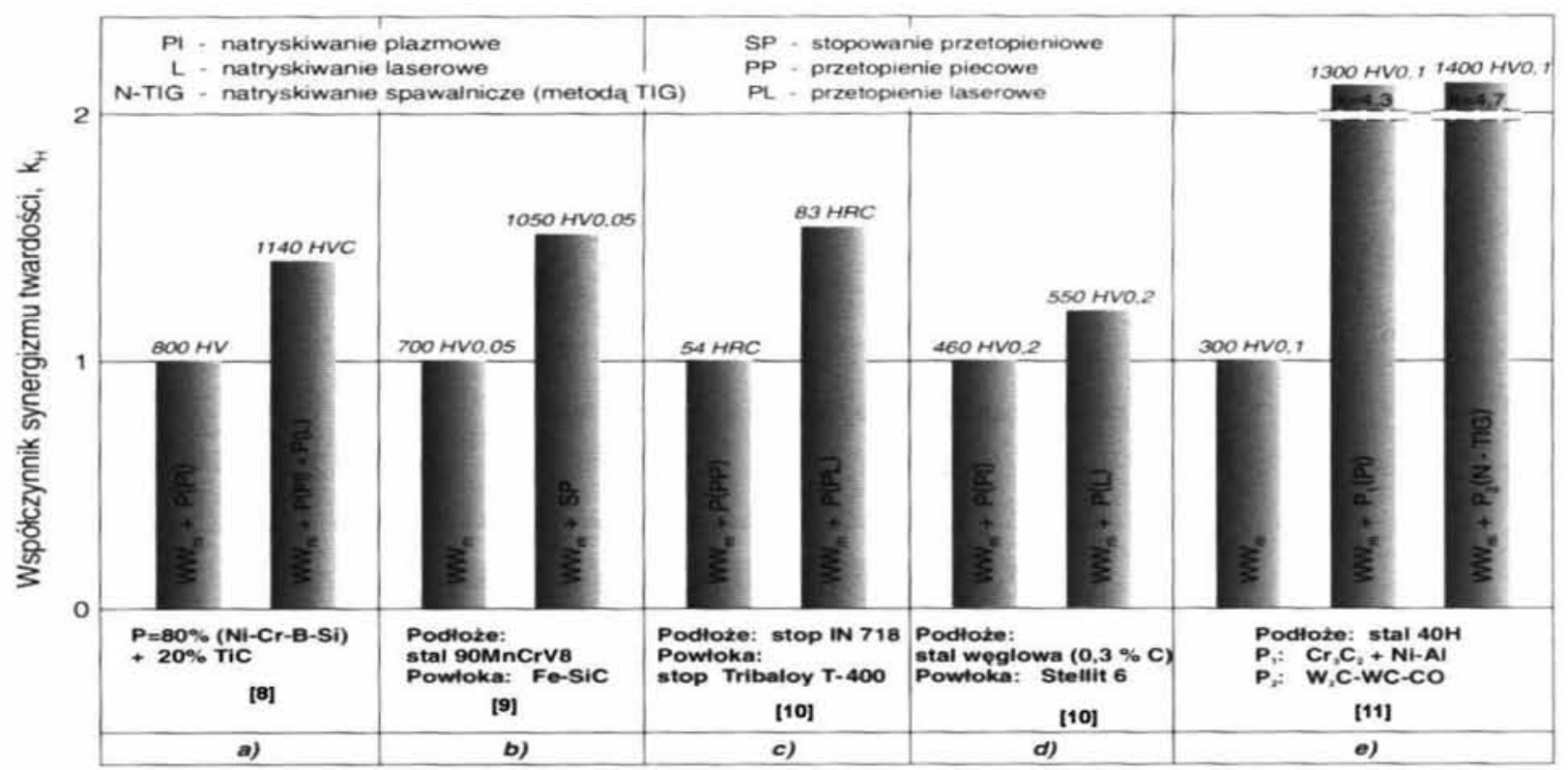

Rys. 7. Współczynnik synergizmu twardości systemów podłoże-powłoka [2] (na podstawie danych z różnych prac): a) powłoka natryskana plazmowo i przetapiana laserowo; b) powłoka stopowana przetopieniowo; c) powłoka przetapiana w piecu i laserowo; d) powłoka natryskiwana plazmowo i laserowo; e) powłoka natryskiwana plazmowo lub spawalniczo

Fig. 7. Hardness synergism coefficient of substrate-coating systems [2]: a) plasma sprayed coating and then laser melting, b) coating alloyed by melting, c) coating melted in the furnace and by laser beam, d) plasma and laser beam sprayed coating, e) plasma sprayed coating or by TIG

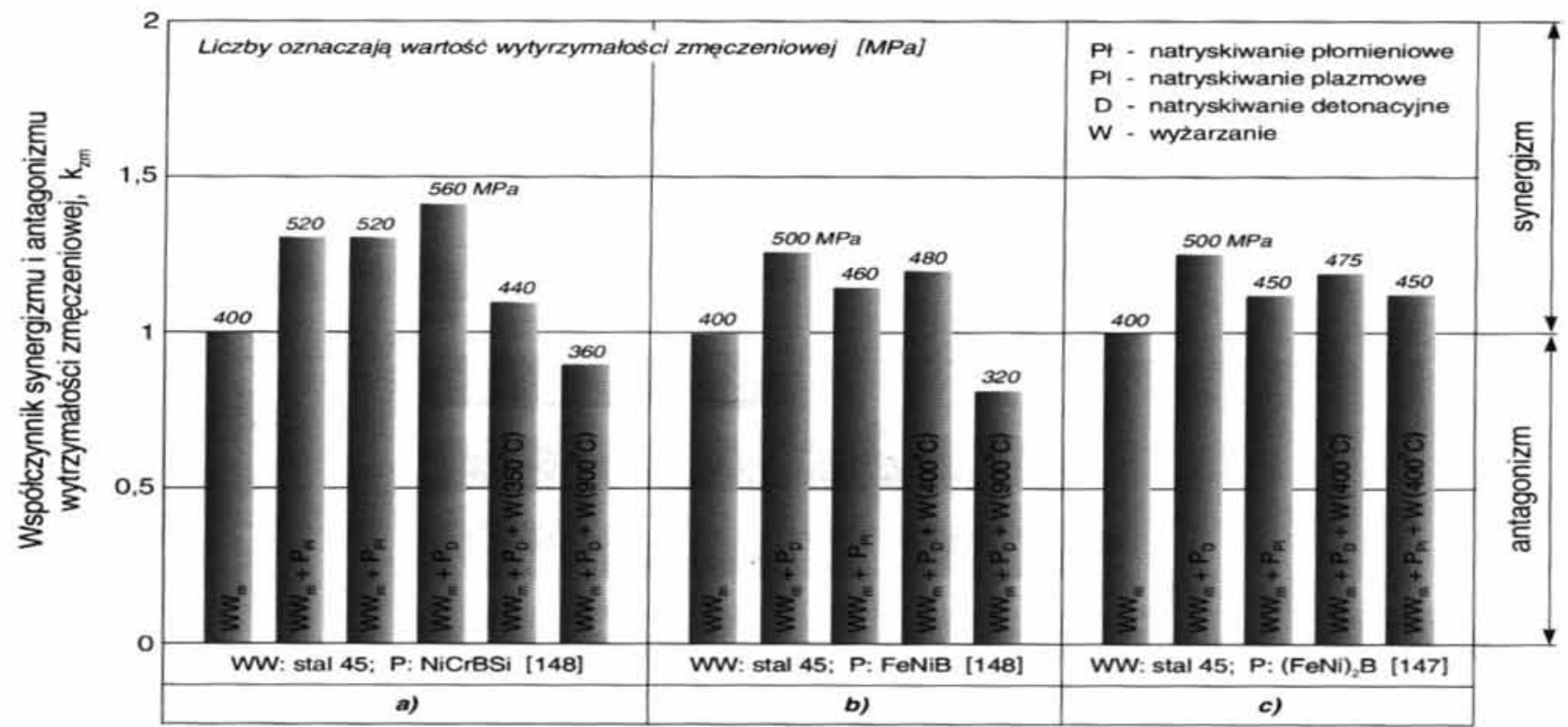

Rys. 8. Współczynnik synergizmu i antagonizmu nieograniczonej wytrzymałości zmęczeniowej giętno-obrotowej $\left(\mathrm{N}=10^{7}\right.$ cykli) systemów: a) stal 45 ulepszona cieplnie - powłoka NiCrBSi, b) ulepszona cieplnie stal 45 - powłoka FeNiB, c) stal 45 ulepszona cieplnie - powłoka $(\mathrm{FeNi})_{2} \mathrm{~B}$ dla różnych sposobów natryskiwania powłok bez lub z następnym wyżarzaniem przez $1 \mathrm{~h}$ (z [2] na podstawie danych z prac [12, 13]) Fig. 8. Synergism and unlimited flexural-rotational fatigue strength $\left(\mathrm{N}=10^{7} \mathrm{cycles}\right)$ antagonism coefficient for: a) quenched and tempered steel 45 - NiCrBSi coating, b) quenched and tempered steel 45 - FeNiB coating, c) quenched and tempered steel $45-\left(\right.$ FeNi) ${ }_{2} \mathrm{~B}$ coating, for different methods of spraying coatings with or without subsequent annealing for $1 \mathrm{~h}$ (from [2] based on data from [12, 13]) 

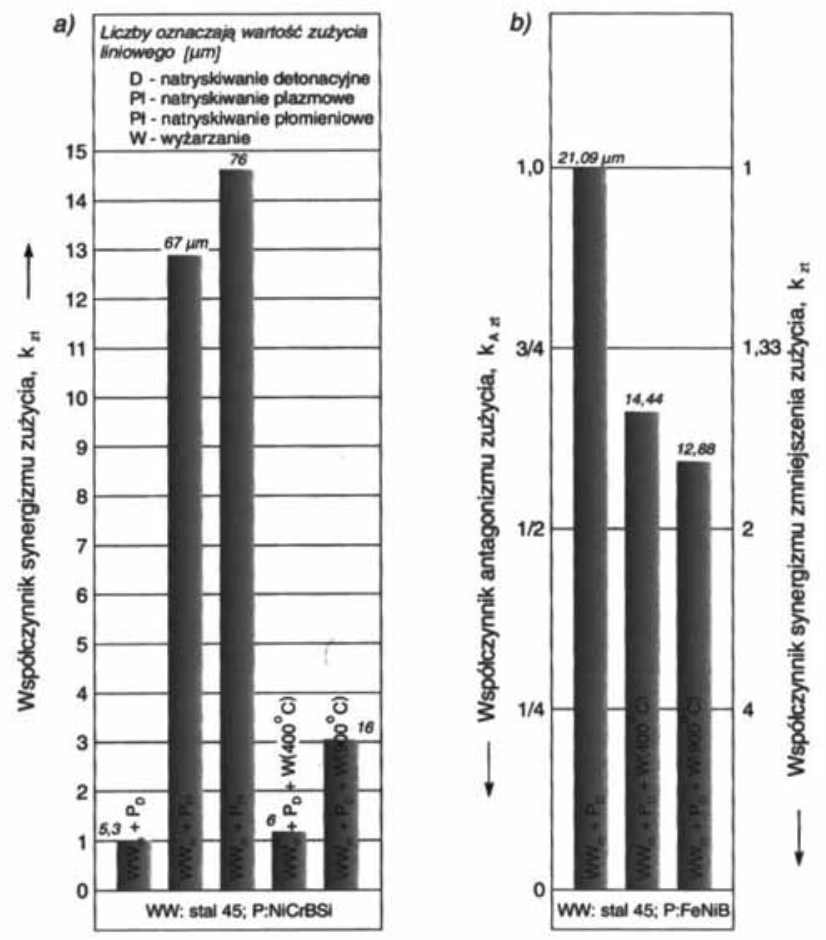

Rys. 9. Współczynnik synergizmu zużycia tribologicznego w układzie: krążek (próbka: stal 45) - krążek (przeciwpróbka: stal 45 + powłoka) przy smarowaniu kroplowym olejem Lux-10 systemów: a) stal ulepszona cieplnie - powłoka NiCrBSi, b) stal ulepszona cieplnie - powłoka $\mathrm{FeNiB}$, natryskiwanych detonacyjnie i wyżarzanych w różnych temperaturach; dla porównania podano zużycie powłok natryskiwanych plazmowo i płomieniowo ( $z$ [3] na podstawie danych z pracy [12]) Fig. 9. Tribological wear synergism coefficient for: disc (specimen: steel 45) - disc (counter: steel 45 and coating) with the lubrication by Lux-10 oil drip in systems: a) quenched and tempered steel - coating $\mathrm{NiCrBSi}, \mathrm{b}$ ) quenched and tempered steel - coating FeNiB detonation sprayed and annealed at different temperatures in comparison with plasma and flame sprayed coatings ([3] based on data from [12])

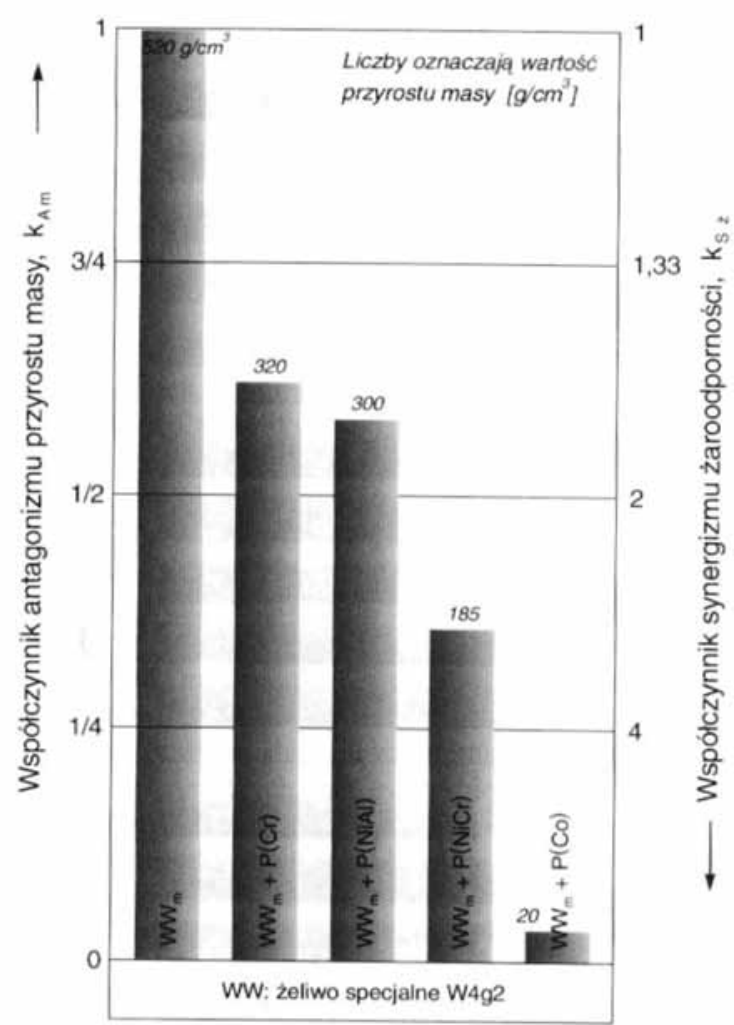

Rys. 11. Współczynnik antagonizmu i synergizmu przyrostu masy, po utlenianiu w atmosferze powietrza w temperaturze $975^{\circ} \mathrm{C}$ przez 180 h, systemów: podłoże - powłoka (różne powłoki natapiane laserowo z proszkowych materiałów powłokowych) (z [3] na podstawie danych z pracy [15])

Fig. 11. Weight increase antagonism and synergism coefficient, after oxidation in air at a temperature of $975^{\circ} \mathrm{C}$ for $180 \mathrm{~h}$, system: substrate - coating (different powder materials laser beam coating ([3] based on data from [15])

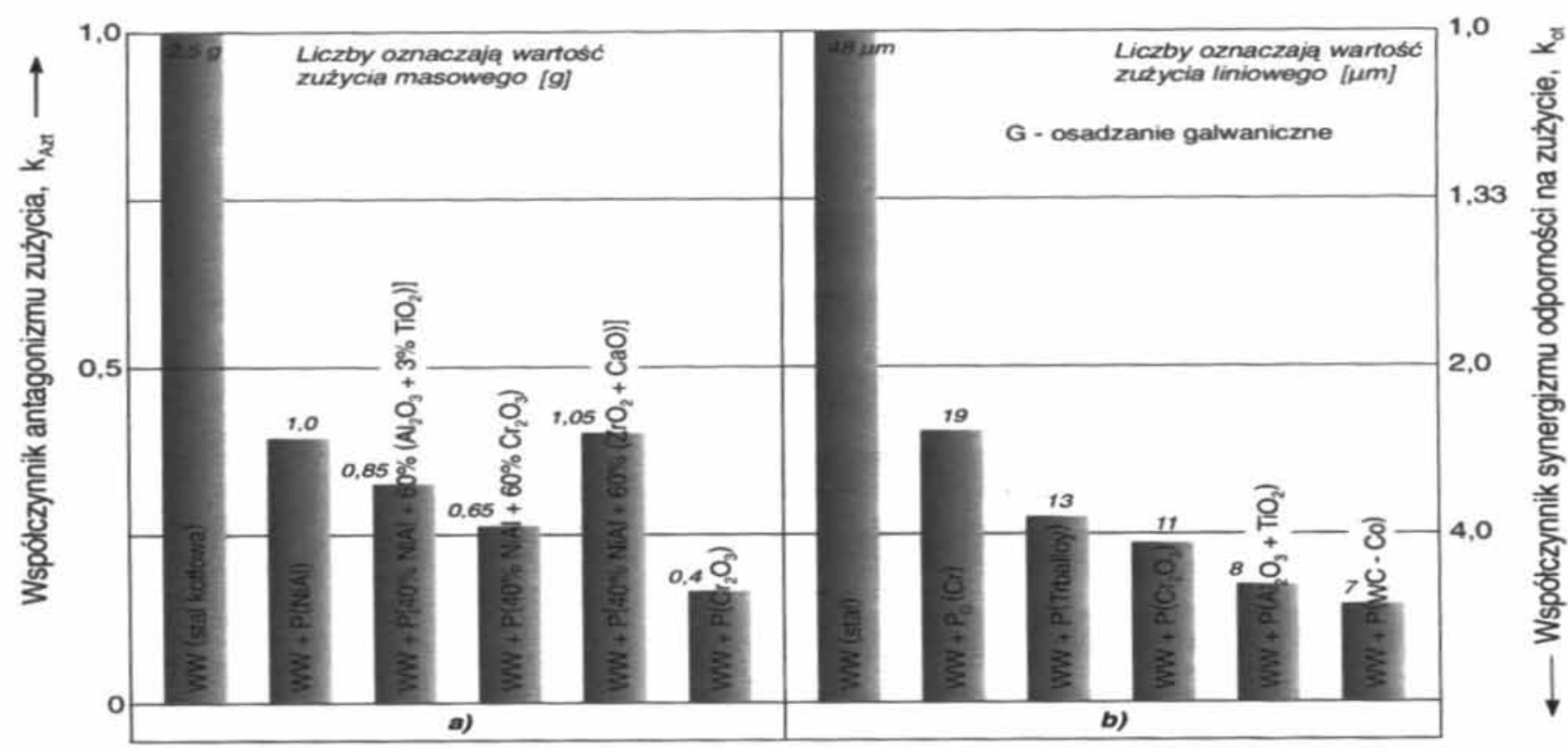

Rys. 10. Współczynnik antagonizmu zużycia (synergizmu odporności na zużycie [3]): a) erozyjnego, systemu: podłoże stalowe - powłoka natryskiwana plazmowo o grubości 0,4 mm [6]; b) ściernego, systemu: podłoże stalowe - powłoka natryskiwana naddźwiękowo [14] Fig. 10. Antagonism wear coefficient (synergism of wear resistance [3]): a) erosion, the system: a steel substrate - plasma sprayed coating with a thickness of $0.4 \mathrm{~mm}([6]), \mathrm{b})$ abrasive system: steel substrate - ultrasonically sprayed coating ([14]) 
współczynnika synergizmu $\mathrm{k}_{\mathrm{s}}$, czyli $\mathrm{k}_{\mathrm{o}}=\mathrm{k}_{\mathrm{s}}$. Dla $\mathrm{k}_{\mathrm{o}}>1$ zawsze występuje synergizm, dla $\mathrm{k}_{\mathrm{o}}<1$ - antagonizm, dla $\mathrm{k}_{\mathrm{o}}=1-$ neutralizm. Teoretycznie współczynnik synergizmu zawiera się w zakresie $1<\mathrm{k}_{\mathrm{s}}<\infty$, praktycznie górna granica wynosi kilka lub kilkanaście. Im większa jest wartość współczynnika synergizmu, tym współdziałanie elementów układu (np. technologii wytwarzania) jest korzystniejsze i tym większy wpływ wywiera na badaną właściwość (np. trwałość użytkową) systemu.

Stosując natryskiwanie cieplne można poprawić wszystkie właściwości użytkowe systemu w stosunku do systemu areologicznego bezpowłokowego - pod warunkiem, że do odpowiednich zastosowań dobrze zostaną dobrane materiały podłoża i powłoki oraz metoda i parametry natryskiwania.

\section{Podsumowanie}

Podobnie jak inne systemy techniczne, również system podłoże-powłoka natryskiwana cieplnie można rozpatrywać w ujęciu funkcjonalnym i fizycznym, ułatwiającym analizę systemu.

Właściwości systemu elementów nie są równe sumie właściwości elementów.
Natryskiwanie cieplne stosuje się do zwiększenia trwałości użytkowej systemów podłoże-powłoka, określonej - w zależności od warunków pracy wzrostem odporności na zużycie przez różne rodzaje tarcia (ok. $60 \%$ zastosowań - to powłoki antyścierne), wzrostem żaroodporności, zwiększeniem lub zmniejszeniem współczynnika tarcia, przewodzeniem ciepła, emisyjności, odbijalności, wzrostem odporności korozyjnej i nieznacznym wytrzymałości zmęczeniowej.

Na rysunkach $7 \div 11$ pokazano na wybranych przykładach, w oparciu o podejście systemowe, możliwości kwantyfikowania ich jakości potencjalnej i użytkowej.

Szacuje się, że w obszarze areotechniki (inżynierii powierzchni) kilka procent zastosowań przypada na systemy natryskiwania cieplnego.

\section{Literatura}

[1] Burakowski T.: Areologia. Powstanie i rozwój. Wyd. Instytut Technologii Eksploatacji - PIB, Radom 2007.

[2] Milewski W.: Kierunki rozwoju natryskiwania cieplnego. Materiały Konferencji Naukowej „Techniki wytwarzania warstw powierzchniowych metali”, Rzeszów, 9-10 czerwca 1988, s. $135-143$.

[3] Burakowski T.: Rozważania o synergizmie $w$ inżynierii powierzchni, Radom, Wyd. Politechniki Radomskiej, 2004.

[4] Bach F. B., Bach Ch., Möwald K., Rothardt T., Babiak Z.: Properties of light metal matrix composite coatings sprayed by gas detonation on Al-, Mg- alloys. Proceedings of International Conference on „Modern Wear and Corrosion Resistant Coatings obtained by Thermal Spraying", Warszawa, 20-21 listopad, s. 63-72.

[5] Żórawski W.: Nowe kierunki rozwoju natryskiwania cieplnego w produkcji nowych części maszyn. Inżynieria Powierzchni 3/2011, s. $10-17$

[6] Morel S.: Powłoki natryskiwane cieplnie. Wyd. Politechniki Częstochowskiej, Częstochowa 1997.

[7] Burakowski T.: System areologiczny - model funkcjonalny i fizyczny. Inżynieria Materiałowa, nr 4, 2011, s. 352-358.

[8] Kovalčenko M. S., Alfinceva R. A., Paustowski S. V., Kurinnaja T. V.: Effects of laser treatment on protective properties on the dry plated coatings. Proceedings of the VII international Congress on Heat Treatment of Materials, Moskva, 11-14 grudzień 1990, s. 39-43.
[10] Naučno-techničeskij progress v mašinostrojenji. Vyp. 9: Sovremennye metody upročnenija poverchnostiej detalej mašin. Meždunarodnyj Centr Naučnoj i Techničeskoj Informcii, Institut Mašinovedenija im. A. A. Blagonravova AN SSSR, Moskva 1987.

[11] Nitkiewicz Z.: Wykorzystanie łukowych źródeł plazmy w inżynierii powierzchni. Seria: Inżynieria Materiałowa, nr 3. Wyd. Wydziału Metalurgii i Inżynierii Materiałowej Politechniki Częstochowskiej, Częstochowa 2001.

[12] Kusiński J.: Lasery i ich zastosowania w inżynierii materiałowej. Wyd. Naukowe Akapit, Kraków 2000.

[13] Babul T.: Zjawiska fizyczne natryskiwania detonacyjnego powłok. Wyd. Instytutu Mechaniki Precyzyjnej, Warszawa 2003.

[14] Babul W., Ziencik H., Babul T., Ziółkowski Z.: Powłoki impulsowo-gazotermiczne. Wyd. Instytutu Technicznego Wojsk Lotniczych, Warszawa 1986.

[15] Żórawski W.: Natryskiwanie naddźwiękowe jako alternatywa dla chromowania galwanicznego. Proceedings of International Conference "Modern Wear and Corrosion Resistant Coatings obtained by Thermal Spraying", Warszawa, 20-21 listopad, s. 73-81.

[16] Napadłek W., Przetakiewicz W.: Stopowanie laserowe na przykładzie elementów rozrządu silnika 359. Materiały Sympozjum Naukowo-Technicznego „Technika laserowa w inżynierii powierzchni materiałów", WAT, Warszawa 19 listopada 1997 r., s. 106-129. 